\title{
Developing Entrepreneurial Spirit Based on Local Wisdom
}

\author{
Muhamad Ahsan (Corresponding author) \\ Brawijaya University, Faculty of Economics and Business \\ Malang, East Java - 65145 \\ E-mail: ahsanciknusi@yahoo.com
}

Armanu Thoyib

Brawijaya University, Faculty of Economics and Business

Malang, East Java - 65145

E-mail: armanuthoyib@gmail.com

\begin{abstract}
Achmad Sudiro
Brawijaya University, Faculty of Economics and Business

Malang, East Java - 65145

E-mail: achmadsudiro@yahoo.com
\end{abstract}

Nur Khusniyah Indrawati

Brawijaya University, Faculty of Economics and Business

Malang, East Java - 65145

E-mail: nur_khusniyah@ub.ac.id

Received: May 5, 2016 Accepted: July 19, 2016 Published: September 19, 2016

doi:10.5296/ijssr.v4i2.9421 URL: http://dx.doi.org/10.5296/ijssr.v4i2.9421 


\section{Abstract}

The purpose of this paper is to explore of entrepreneurial spirit development at the Pesantren (Islamic Boarding School) Sunan Drajat which led by Kyai Abdul Ghofur in local setting one of Islamic propagator legends in Indonesia, Sunan Drajat. The research method used ethnography approach. The techniques of collecting data used were participant observation, interview and focus group discussion. Techniques of analyzing data used were content analysis of interview, domain analysis, taxonomy analysis, component analysis and finding culture themes. The findings are entrepreneurial spirit development at the Pesantren Sunan Drajat has been inspired by catur piwulang philosophy as the core in giving spirit to the students and local communities. The entrepreneurial spirit development has produced a distinctive model in preparing Islamic entrepreneur generations for the future. As practical implication, the findings can be used as reference to develop entrepreneurial development especially at pesantren in Indonesia. The model also can be used to motivate another pesantren to develop an institution through the local economic based activities to become autonomous institution and not depend on other parties. Originality of this research is to reveal the leadership role and local wisdom in developing entrepreneurial spirit at the Pesantren Sunan Drajat and the community surrounding.

Keywords: Kyai Abdul Ghofur, Entrepreneurial spirit, Pesantren Sunan Drajat, Local Wisdom

\section{Introduction}

Pesantren (Islamic Boarding School) Sunan Drajat (PSD) is located at the northern coast of Java island, it is a famous pesantren, in Lamongan, East Java. This pesantren is led by Kyai Abdul Ghofur and having approximately 7000 santri (students) (Hasan, 2012) and fourteen developing business units.

Sunan Drajat is one of the Wali Songo members whose name adopted by the pesantren which located at Banjarwati village. The Sunan Drajat heritage sites are still kept until today, as well as his taught philosophy. The philosophy is known as catur piwulang, the philosophy said that: Paring teken marang kang kalunyon lan wuta (give them who are blind and walking at the slippery path a guiding stick), Paring pangan marang kang kaliren (give them who are hungry some foods), Paring sandang marang kang kawudan (give them who are naked some clothes), Paring payung kang kodanan (give them who are in the middle of the rain an umbrella) (Roesminingsih, 2012). The catur piwulang philosophy are parts of pepali pitu (the seven basic teachings) as quoted by Sunyoto (2012): 1) Memangun resep tyasing sesama (always make other people happy). 2) Jroning suka kudu eling lan waspodo (always remember the God and aware when you are happy). 3) Laksitaning subrata tan nyipta marang pringga bayaning lampah (in reaching lofty ideals you have to ignore any obstacles). 4) Meper hardaning pancadriya (always suppress your sensory appetites). 5) Heneng- hening henung (in silent will reach silence, and in silence will reach noble freedom). 6) Mulya guna panca waktu (in reaching the phisical and spiritual glory, five times praying is needed). 7) Menehono teken marang wong kang wuto. Menehono mangan marang wong kang luwe. Menehono busana marang wong kang wuda. Menehono pangiyup marang wong kang kaudanan (Give guiding 
stick to the blind). Give foods to the hunger. Give clothes to those who don't have one. Give shelter to those who are in rain).

The Kyai of Pesantren Sunan Drajat is known as an entrepreneur Kyai (Rofiq, 2011). He often gives his own money to take care the poor santri (Salim, 2007). It is because the pesantren has several business units as the money machine, for example the noni garden which is 10 hectares, business of Sunan noni juice, the production of compound fertilizer with label of Guano Phosphate, production of livestock and fish feed, Aidrat bottled water factory, cattle and goat fattening business, religious proselytizing radio of Persada 97,2 FM, Persada television, Trading Business of Sunan Drajat, cooperative and Baitul Mal wa Tanwil (BMT), hajj and umroh travel agent, and car rental (Pesantren Sunan Drajat profile, 2012). With the mission do not produce unemployment santri, therefore PSD keep developing its business unit as a place for the santri to learn so they will have experience after they leave the pesantren because the fact that the number of unemployment in Indonesia always increase each year as quoted in Republika on line. There is increasing of 1,3 million unemployment each year (Putra, 2012). In 2012 up to February the number of unemployment reached 7,6 million people with open unemployment rate $6,3 \%$ (Feb, 2012).

To minimize the unemployment rate, increasing the entrepreneur number is one of precise solutions, as Van Praag and Versloot (2007) stated that entrepreneurs had important and specific role in economy. They create job vacancy, give contribution to the productivity improvement, produce and commercialize innovation, and also create conducive environment. The statement of Van Praag and Versloot was affirmed by the statement of Carsrud and Brannback (2007:5) which stated that the more entrepreneurs in a country, the better economic growth will be in that country. Hence, to develop the number of entrepreneur, entrepreneurial introduction to the children is needed in order to improve their autonomous spirit. Due to the fact that entrepreneurship can be the economic driving machine of a country (Fayolle, 2007a: 14-15); the booster of economic growth (Hodgetts and Kuratko, 1995; Li et al. 2012:948-961; Casson and Wadeson, 2007:239-262), the creator of competitiveness and job vacancy (Thurik and Wennekers 2004: 140-149); the economic mover (Schaper and Volery, 2004); the alternative to solve unemployment and poverty problems (Bogan and Darity, 2008). This linear logical pattern can be a reference to answer the question why many countries are trying to improve the entrepreneur number. As the important note, small companies in large number are having convincing role in developing the world's economy (Bygrave, 1994; Timmons, 1994).

To increase the entrepreneur number massively is not an easy matter to do because to be an entrepreneur is about mental problem. In the other hand, there are still debates about whether an entrepreneur is born or can be created (Akola and Heinonen, 2006). The contra group question whether entrepreneurship is knowledge or arts (Saee, 1996; Shepherd and Douglas, 1996; Jack and Anderson, 1998; in Henry, Hill, and Leitch: 2005); in contrast, the pro group believes and says that entrepreneurship can be developed and improved through education and training (Vesper, 1982; Clark et al., 1984; Kantor, 1988; Saee, 1996; Henry et al., 2003 in Henry, Hill, and Leitch, 2005). From the polemic, there is a possibility to improve the entrepreneurial passion through education, especially in pesantren although everything is still 
depending on the intention of each person.

The potentials of pesantren in developing and propagating the spirit of entrepreneurship to increase the new moslem entrepreneur number in the future are very convincing. The potential is urgent if connected to the social phenomenon nowadays because the history of pesantren in Indonesia actually that has had autonomous spirit as stated by Haedari (2012)

"Since the beginning of pesantren development, kyai has taught about being autonomous to all santri by using the existing extensive land for cultivation, fisheries, and many other as the way to fulfill the daily needs in pesantren. Along with the time, the extensive land becomes narrower because of the ownership transfer (inheritance) to the next generation of the kyai. Traditional productivity patterns were left because of the limited land availability. Otherwise, it will challenge the pesantren to create new creativity in order to make it more productive and creative."

The statement of Haedari (2012) explained that entrepreneurship is not a new thing in pesantren. Otherwise, entrepreneurship has become a challenge for pesantren in the globalization era to bring back the spirit.

\section{Literature Review}

\subsection{Islam and Entrepreneurship}

Entrepreneurship terminology is not always dominated by researchers and published book writers in the west. Entrepreneurship terminology is varied in kind and has different local contents although the aim is same the autonomous spirit.

Talking about entrepreneurial spirit, it becomes more interesting especially in Indonesia whose population are mostly Moslem. Do you know why? Because the Prophet Muhammad SAW (peace be upon him), was a businessman. As stated by Nadiri (2009) "The prophet of Islam, Muhammad was a business man himself. He not only brought wealth and profit to his community in Medina and Mecca, but his successors also established vast trading networks and treatises to bring prosperity to the Islamic empire which covered a vast territorial expanse." Thus, the normative dimension of Islam encourages self-employment. What was said by Nadiri is affirmed by hadiths from Bukhari and Ibnu Majah (Zabidi, 2002) about autonomous spirit,
"Someone who takes a wisp of rope, then cut tree's branch and tie them down with the rope, then sell it to fulfill his/her daily needs and give it away as alms is better than someone who beg for alms to someone else. Either the giver will give the alms or refuse to give the alms." (HR. Bukhari and Ibnu Majah).

Above hadith means that actually Islam has put the basic entrepreneurship to its followers. Hard-work, autonomy, and not relying life on others by doing the right trading activity, which has been given example by the Prophet, is the real entrepreneurship. Islam gives entrepreneurial example by trading, distributing products from one place to others. History has recorded that the role of entrepreneur (Faruqi and Faruqi, 1986; Madjid, 2012) in 
distributing their products as one of the factor of Islamic religion propagating throughout the world. It is in line with surah Al-Ahzab verse 21 that said: "Verily, In the Apostle of God you have a good example for everyone who looks forward [with hope and awe] to God and the last day and remember God unceasingly". The verse implies to all Moslem that Prophet Muhammad has given example of a good entrepreneurship by being an honest and reliable entrepreneur.

To trigger the autonomous spirit, entrepreneurship education is needed as the way to motivate the entrepreneurial desire especially to the non-business students (although it is still debated). This action is intended to be the first motivation to create new entrepreneurs generation in bringing the new ideas and making the entrepreneur community (Otto, 1999 in Fayolle, 2007b:54). Entrepreneurial spirit has become the issue in this $21^{\text {st }}$ century (Kuratko, 2007) and can be learnt and introduced since childhood. As reported at the World Economic Forum of Switzerland in 2009, it was reported that the target of entrepreneurship learning group was better for youth aged 6-22 years old (Volkmann et al., 2009:26), it means that those ages have golden opportunity since they are in primary school up to the higher education (Oosterbeek, van Praag and Aukeljsselstein, 2010). The report of World Economic Forum in Switzerland has been appreciated by the United State of America as a country, because this country has taught entrepreneurship in more than 1600 schools and more than 2.200 programs (Katz, 2003 in Landstorm, 2006:4).

The World Economic Forum suggests learning entrepreneurship at first, in the Islamic context it was actually done by Rasulullah SAW. In his life, Rasulullah SAW had built and dealt with business since 12 years old. Even his prophecy period was shorter (23 years) than his business period (25 years) (Antonio, 2011:12). The implication, we need to give entrepreneurial spirit from the younger ages for Moslem generation today. As a developing country, entrepreneurial development is really needed and has become important global economic phenomenon nowadays (Lingelbach, De La Vina and Asel, 2005).

\subsection{Entrepreneurial Spirit in Pesantren}

Entrepreneurial spirit refers more to the human activities, spirits, and enthusiasm as shown by entrepreneur attitudes (Nandram and Samson: 2006). Entrepreneur is a figure who easily adapt to the change and fast learner (Pitts: 2008). According to Klein which is quoted in Strong (2009) the word of spirit in entrepreneur is a soul, an energy that activates human potentials to create, innovate, find, work, with desires to pursue vision although has to face challenges, obstacles, and risks. Bygrave and Zacharakis (2011) said that organizations really need entrepreneurial spirit in their growth, as well as pesantren as an education institution.

In several pesantren, the spirit is seen and real but in several others still do not have the spirit. Teaching patterns, knowledge transfer, and understanding about entrepreneurial context itself is still narrow and need to be expanded. Even the pesantren potentials to develop with its economic strength are very high. Empirical evidence showed that the pesantren development is really depends on the role of kyai in adapting to the environmental changes. Sukamto's (1999:17) findings showed that the changes and adaptation occurred in pesantren proved that the Kyai able adapt to the societal development. Kyai also will to review the religious 
understanding, including social aspects as well as find new patterns in the leadership regeneration in pesantren.

Development potentials of the entrepreneurial spirit at Pesantren in Indonesia become more opened because the population mostly moslems $(86 \%)$ live in rural area $(50,21 \%$ - Central Bureau of Statistics data in 2010). In East Java with population approximately 37,5 million people, more than 52 percent live in rural area (according to census data of 2010). This data showed that East Java population is still concentrated in rural area which is identical with pesantren education as the genuine Indonesian education as the beginning era of Melayu Nusantara (Dhofier,2011). According to the data of Minister of Religion, the amount of pesantren which spread out in the rural area is about 4.404 (www.kemenag.go.id;2011). Those pesantren have become choices for school-aged children in Indonesia to study.

\subsection{The Role of Leadership in Strategy Application}

Peng (2009) has summarized strategy into three parts, there are strategy as plan, strategy as action, and strategy as integration. Strategy as plan concentrates on how to make plans, introduce it, and make decision in moving organization in order to pursue vision. Strategy as action concentrates on how to apply and behave in pursuing the organization vision by using the available uniqueness. Besides, strategy as integration focuses on choosing long term purposes of organization, doing coordination also defending and improving competitive benefits in pursuing the organization vision.

In order to develop and grow, profit and non-profit based organizations need strategic management. Strategic management is directly related to the organization resources in managing challenges and using opportunities. Strategic management is involving strategic development and policy formulation to reach the vision and mission of organization. In the process, the focus will be given to both external strategies and internal capabilities. Strategic management also offer framework where an organization can adapt to the uncertain environments and future (Steiss, 2003).

Leadership and strategy are the two inseparable coin sides because when talking about the change it means talking about strategy and leadership (Abell, 2006). According to Europe Foundation for Quality Management (EFQM) it said that “the behaviour of an organization's leaders (should) create ... clarity and unity of purpose within the organization, and an environment in which the organization and its people can excel' (EFQM, 1999)." This showed that leadership becomes the key issue in strategies, value sources, and the competitive advantages. Leadership has become the key issue in long term strategy direction, defended stability, and still survive in its developed business. Leadership is also responsible for the next strategy focus and developing knowledge based values, culture, and ideology; form and relation, core advantage; finance and resources, added value and competitive advantage also management strategic process (Morden, 2007:331).

\section{Methodology}

Ethnography approach (Fetterman,2010; Murchison, 2010) is used in this research which has been done in Pesantren Sunan Drajat since November 2012 until March 2014. The key 
informant is the leader of pesantren Sunan Drajat, that is Kyai Abdul Ghofur. To explore the role of Kyai Abdul Ghofur in developing entrepreneurial spirit in pesantren and the community around, the researcher lived with pesantren community at least 3-4 days in a week. To explore what has been done by Kyai Abdul Ghofur so far, the researcher needs perception from the informants who has known him for about 2 years by doing interview with 57 supporting informants. The supporting informants were chosen intentionally and by snowballing. The supporting informants are consist of family, santri, dormitory administrator, business unit and education administrators, alumni and business partners.

Data collection in this research was done by participative observation (Spradley, 1980 and 2007; Vanderstoep, 2009; Wolcott, 1999), by getting along with the informants in daily life and doing serious interview to the key informant and the supporting informants. Getting along with the informant in daily life was done by living in the research location, following any Islamic recitation and scrutinizes all the messages. Observing behavior of key informant to find out how he behaves in developing and propagating the entrepreneurship in the pesantren and community around. Observing his family and santri life, doing interview with 'internship' santri, doing interview with each male and female boarding house chairman and also doing focus group discussion; business units that have been developed and doing interview to several business unit leaders. The researcher also doing interview to population around the pesantren, doing interview to the pesantren's business partners, doing interview to the alumni that became partners, and other information sources that can give additional information to answer the purpose of the research.

Data validity test in this research used four standard criteria offered by Lincoln and Guba (1985), Paton (2002), and Creswell (2007). It was 1) credibility standard, 2) transferability standard, 3) dependability standard, 4) confirmability standard. The used analyses are interview analysis, domain analysis, taxonomy analysis, component analysis and finding culture themes (Spradley: 1980 and 2007).

\section{Findings and Discussion}

\subsection{The Role of Entrepreneurial Leadership of Kyai Abdul Ghofur}

In building entrepreneurship spirit at PSD, the role of entrepreneurial leadership of Kyai Abdul Ghofur is undeniable. The role is still irreplaceable by staffs and other santri who are believed to manage the Pesantren Sunan Drajat. The role of Kyai Abdul Ghofur is not only in deciding who is going to be the leader of each business unit which under the Sunan Drajat Foundation but also leaders in every education unit.

In process of building and developing entrepreneurial spirit in PSD, Kyai Abdul Ghofur leadership style is said by his follower as authoritative leadership style. It is occurred because the kyai don't want unproductive discussion. For pesantren community, Kyai Abdul Ghofur behavior is reckoned as the leadership style which is similar to militaristic, authoritative or 'todongan' as said by informant AQW-53 repeating of Kyai Abdul Ghofur said, "musyawaroh-musyawaroh, nggae jeding ae nggak mari (too much discussion but only constructing bathroom is not yet done)." What is said by Kyai Abdul Ghofur showed that he 
wants to save time in the middle of hectic activities; therefore he dislikes long-time discussions because Kyai Abdul Ghofur wants a real result (task oriented). Just like he said in interview session:

"I still use guided democracy, what I say...everyone should follow me, if there is fight the pesantren will not survive... Indonesia should be like that ... Indonesia needs that kind of leader"

Kyai Abdul Ghofur has translated and applied the Sunan Drajat philosophy (wenehono) by showing his nationalism spirit through his hard-working and full discipline. Kyai Abdul Ghofur realizes that to get out of poverty, strong willingness and hope need to be included. The business units which are run by Kyai Abdul Ghofur is an example for the next Moslem generation in the future as he said,

"...but if only drink, we should not buy American product, Coca Cola, Fanta, Danone are American, cars made by China.. Then what the Javanese can do? it is the government..... But never mind....if want to drink, drink Aidrat because the profit for pesantren..... The sea water can become Samudra salt.... the sea water can become salt..... of course it can...Aidrat taste similar with Aqua... the students can realize... their parents can drink Aidrat.... it is example not only theory... it is practical"

What is said by Kyai Abdul Ghofur showed that the application of Sunan Drajat philosophy is an autonomy philosophy that resulting in entrepreneurial spirit and developing nationalism spirit. The love of country is shown by not wanting our resources are taken over by the other country. This is not a new thing because long history of Indonesian struggle in fighting imperialism was also encouraged by religious leaders. Kyai realizes that colonialism occurred today is not by using weapon that destructs our country, it is economic power by exploiting natural resources instead.

Sunan Drajat nationality philosophy is justified by informants BUD-23 (Chinese entrepreneur). According to BUD-23 in interview session in his office, he said:

“... So I can enter into the grave... I read... that Sunan Drajat was not only a theologian but also statesman.... It is written "how to make all people get enough food, enough clothes, enough shelter, enough health, and enough education." It is a vision of a statesman. Its Raden Qosim who known as Sunan Drajat is a statesman."

Kyai Abdul Ghofur strongly holds commitment to continue the Sunan Drajat ambition. His role reflects the role of a leader, theologian, and also a businessman. The complete role and seldom owned by other Kyai. In the Kyai Abdul Ghofur leadership era, awakening of pesantren Sunan Drajat done by adopting Sunan Kalijogo words, "get the fish without making the water dirty" in his communicative missionary endeavor. This philosophic message is written in PSD mission and shows that he is a moderate person in pursuing his missionary endeavor purposes as the organizational purposes. 


\section{Mll Macrothink}

There are dualism roles in the Kyai Abdul Ghofur, kyai as an entrepreneur and kyai as a leader and as a theologian at once. This is not a new thing according to informant (BUD-23), before become a kyai, Abdul Ghofur is an entrepreneur. It is also said by informant IMN-9, the caretaker of Sunan Drajat grave, he said that:

"Yes it is... before becoming a kyai he is an entrepreneur... he taught reading holy Qur'an when he had already worked, work in this industry"

This showed that Kyai Abdul Ghofur is consistent in applying the Sunan Drajat philosophy through his own understanding that to become a kyai, it has to be rich or enough in knowledge at first, therefore doesn't need to rely on others, having self-esteem and respected. Kyai, santri, and pesantren administrator understand the meaning of the Sunan Drajat philosophy. Moreover, kyai has clearly explained that in taking care of business unit should be standardized by the philosophy and everything goes back to the needs of pesantren. PSD economic autonomy is a reflection of Sunan Drajat philosophy that is managed by kyai to make the dream of making the pesantren Sunan Drajat become the biggest pesantren in Indonesia comes true.

Entrepreneurial leadership of Kyai Abdul Ghofur has become entrepreneurial virus in his community, unlimited to his santri only but to the teachers, administrator, alumni, and community around pesantren. Kyai Abdul Ghofur has created his own vision through his organization (foundation) to become the biggest pesantren in the future. According to Fernald et al. (2005) the characteristic of the combination between entrepreneur and leader personality can be found in Kyai Abdul Ghofur and can be drawn as follow:

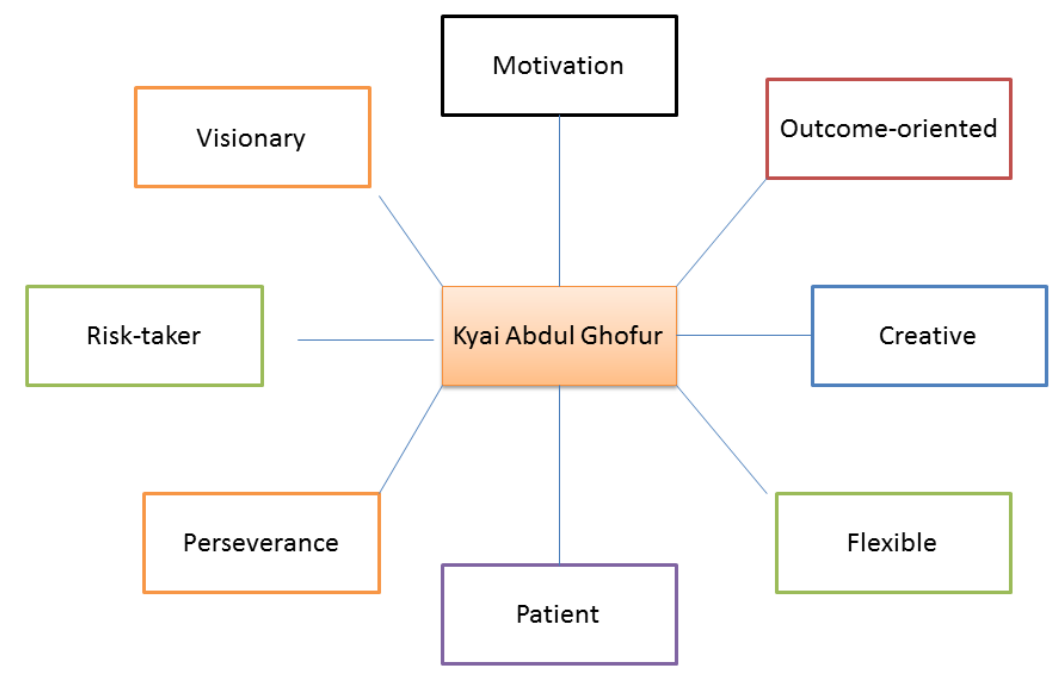

Figure 1. Characteristic of Entrepreneur and Leader in Kyai Abdul Ghofur Sources: Processed by researcher (2014) 
Characteristic of the combination between entrepreneur and leader has given contribution in the role as a leader in Kyai Abdul Ghofur by always consistent in taking humanities principles. The humanities principles which held by Kyai Abdul Ghofur showed that he has social consideration to the existing businessss before creating the new similar business. This showed that Kyai Abdul Ghofur keeps entrepreneurial spirit that has developed in around communities. For kyai Abdul Ghofur, the harmonization with community is a must as the implication of love to others. This is totally different with the modern patterns which are very capitalist. Kyai Abdul Ghofur's principles reflect Islamic behavior in the other forms. A noble behavior in keeping and developing entrepreneurial spirit for others. It becomes social capital for Kyai Abdul Ghofur in having interaction horizontally with the communities living around pesantren. Due to the role of leader according to Islam is that as the servant and guard (Beekun and Badawi, 1999), serving the community and his followers and guarding the communities in wide contexts.

The role of entrepreneurial leadership of Kyai Abdul Ghofur has been motivated by Sunan Drajat philosophy as the form of interpretation of still kept local wisdom. What Kyai Abdul Ghofur does showed that Kyai Abdul Ghofur is consistent in applying what Sunan Drajat philosophy has taught to always give with interpretation that to be a kyai needs to be rich first. This model is taught to all his santri through his advices in regular recitation. If you want to be a kyai, don't be a poor kyai, kyai should be rich, and kyai should have a lot of wealth. The statement of Kyai Abdul Ghofur has a deep meaning that giving is far better than receiving as it is said by Prophet Muhammad SAW:

"The alms giver is better than alms receiver. Prioritize people who depend on you. The best of alms are the one from rich people. Whoever working hard to avoid asking for alms, Allah will save him from asking for alms and whoever is satisfied with Allah gives, therefore Allah will give him adequateness" (HR. Bukhari no.1427).

This hadith has affirmed Kyai Abdul Ghofur's statement that to be a kyai has to be rich. The statement is not opposing with the hadith said by Prophet Muhammad SAW, that it is never encouraged to give alms except for those who are rich. To become rich, working is surely needed and also doing the best to financing himself. This spirit is an autonomous spirit that identical to entrepreneurial spirit.

The other important role is that Kyai Abdul Ghofur has become agent of change by willing to create autonomous generation and having nationalism spirit. What Kyai Abdul Ghofur has done nowadays is as a form of facilitating and giving his santri instruments to become real autonomy. Background of the entrepreneurial leadership and nationalism of Kyai Abdul Ghofur has been taught to his santri. The process of teaching his santri about nationalism spirit was done through his education and direct proving that institution like pesantren also able to handle and develop business units. The outstanding nationalism spirit of Kyai Abdul Ghofur is an open fight to the government which uncaring to the problem of natural resources exploitation for national prosperity. Kyai Abdul Ghofur doesn't want massive capital flight to the other countries as the result of Indonesia's natural resources exploitation. The findings 
either from field or direct interview to Kyai Abdul Ghofur, santri, alumni, or seminar video done by entrepreneur community in Sunan Drajat College (STAIRA) showed that Kyai Abdul Ghofur always repeated the same words with the same meaning that "why just drinking water this country couldn't do?" Kyai Abdul Ghofur has proven his words because Aidrat drinking water industry which is located in the pesantren has been developed. The positive side of Aidrat drinking water industry operation is that santri don't need to pay more in fulfilling the daily needs of drinking water, it is all freely given.

Kyai Abdul Ghofur personal vision is want to make PSD as the biggest pesantren in Indonesia and creating autonomous alumni is a big dream that still in the process. The pursuit of that vision is getting closer if seeing the development of the pesantren Sunan Drajat since it was led by Kyai Abdul Ghofur. Start from 5 santri, it has increased into approximately 10.000 santri. Start from having 4 hectares land assets, it has increased into 160 hectares land assets. Start from only one truck vehicle, it has increased into hundreds of trucks (approximately 600 trucks). These are the proof that Kyai Abdul Ghofur is the agent of change. He is brave enough to make plans in pursuing his vision and out of the traditional role of kyai that kyai is someone who is prominent figure and has deep knowledge in religion.

Management practices that have been done in pursuing the great vision of an organization can't stand alone without combining any existing elements. For example is culture. Religious value also plays a key role in motivating the development of entrepreneurial spirit in PSD. This is not contradictive to Ibnu Khaldun said in Sidani (2008) that the context of entrepreneurship role can't be separated from the local cultural context where the leader lives.

Regarding to Barker and Coy $(2004$; 91-95) said that strategy is not adequate in pursuing organization vision, strong culture was also needed, and both of them should walk along. The cultural strength in the pesantren with Sunan Drajat philosophic base and synergized with Kyai Abdul Ghofur strategies to pursue organization vision able to shorten the pursuit time. Attitude, commitment, and values of Kyai Abdul Ghofur will become strong culture in the future. Besides that Kyai Abdul Ghofur's abilities, talents and capability in managing and developing pesantren is a part of strategies that has run well. What Barker and Coy said was shown in the role of Kyai Abdul Ghofur in engineering the development of entrepreneurial spirit by always holding Sunan Drajat philosophy as the local wisdom. Externalization process or adaptation has done by using Sunan Kalijogo philosophy, "get the fish without making the water dirty" that become the mission of organization in pursuing its vision is a very precise strategy. Sunan Kalijogo philosophy implies that Kyai Abdul Ghofur is trying to avoid conflicts in the process of pursuing his vision. He doesn't want to make condition become 'dirty' but his vision can be pursued. Therefore what Barker and Coy described can be adopted and visualized through Figure 2 below: 


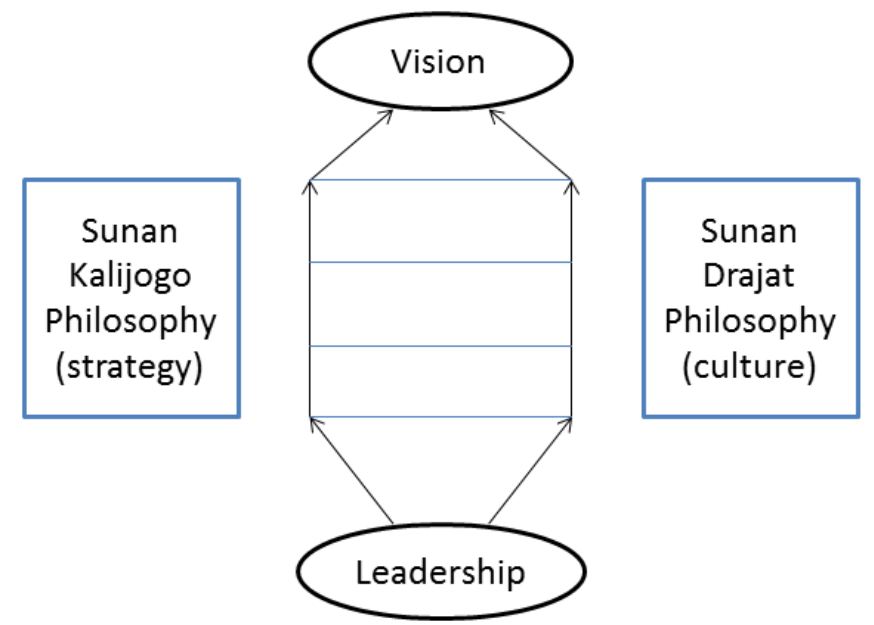

Figure 2. Synergy of Culture and Strategy in PSD

Source: processed by the researcher (2014)

The finding analysis that is shown above has produced proposition:

"Entrepreneurial leadership of Kyai Abdul Ghofur by using 'guided democracy' style and wrapped with the local wisdom has successfully changed the perspective about the importance of autonomy for individual (santri), group (institution) and community in order to get glory in the world and in the hereafter."

\subsection{The Role of Entrepreneurial Character of Kyai Abdul Ghofur}

The entrepreneurial character in Kyai Abdul Ghofur has become inspiration for his family and his santri. Kyai Abdul Ghofur has been idolized by the santri not only as a kyai but also as an ideal man and successful businessman. Kyai Abdul Ghofur spirit in business has inspired his santri as his students who always and often meet him and see his struggle in daily life. Example that is shown has become the spirit in forming life atmosphere in this pesantren. This is one of Kyai Abdul Ghofur mission in building business unit in this pesantren. Besides that, it is not only to develop nationalism spirit for his santri, but also creating this business unit as example for his santri that learning is not only about theory but also in practical life, as he said in the interview:

"If the there is a large profit of drinking Aidrat for pesantren... the sea water can become Samudra salt... the sea water can become salt... of course it can...Aidrat flavor is just the same with Aqua... it can... the students realize.. The sea water can become salt...... of course it can...Aidrat taste similar with Aqua... the students can realize... their parents can drink Aidrat... it is example not only theory... it is practical"

Strong entrepreneurial character in Kyai Abdul Ghofur has caused as if PSD lost its own function as pesantren (MIF-4). From the statement being stated by MIF-4, the fact that Kyai Abdul Ghofur can be said as an entrepreneur Kyai is not something that exaggerated. It is the 
name for Kyai Abdul Ghofur that showed up when the researcher discussing about this thing with his friends.

Characters of Kyai Abdul Ghofur in building and developing the pesantren and business unit in it are a reflection of Sunan Drajat philosophy. Giving (wenehono) has become the keyword in his life journey until today. The word 'giving' is also becoming lesson for santri and community around pesantren that asking is something which is not good to do. As it was said by Kyai Abdul Ghofur in the morning recitation about his closeness to 'government' was not used as the way to ask the government to build his institution. Here are some of the words in his speech:

"If I asked to Mr.Harto (the past president of Indonesia) probably it will not become the pesantren, it may become security place in a village instead."

The speech that he gave in regular recitation in the morning shows his integrity in taking the message of Sunan Drajat. The speech he gave in front of santri is a part of example and strengthens motivation that explained the asking activity is not something that suggested. It means that giving is better than asking, giving is better than receiving. The spirit of giving is better as the implementation of ability and autonomy, someone's spirit who fights to be better in his life without burdening others.

Entrepreneurial character in Kyai Abdul Ghofur has become trade mark to PSD. His spirit accompanies the development of Pesantren Sunan Drajat since this pesantren has been reactivating until today. When we are talking about PSD, it means that we are talking about Kyai Abdul Ghofur. Entrepreneurial character of Kyai Abdul Ghofur has shown before he became a known kyai today. Before PSD has developed like today, actually Kyai Abdul Ghofur has built up himself to become someone who is autonomous through several occupation that he has done such as, magician, acrobat player, trading, and many more. His life background has turned out to be his personal character. Character as a Kyai who is also a guardian, PSD foundation leader that has a lot of education and business units and become a role model to stakeholders. The figure of kyai has become a role model in PSD and community around outside of PSD especially to the Majlis Taklim (followers of recitals) which are spread out in pantura (north beach area) stripe and around it.

Actions done by Kyai Abdul Ghofur have strengthened various entrepreneurship definitions that has been exist. Twelve (12) characters in Kyai Abdul Ghofur have been told by former researchers. The important point in this topic is the presence of outstanding willingness in Kyai Abdul Ghofur to create unlimited value which is not only from human resources but also from natural resources around pesantren. The difference of this finding to the former findings is the presence of 'prophet motive' in this finding. It is because of the research setting that is located at pesantren and also because Islam is known as a way of life for the believers. Every activity that has been done by Moslem will be ended up to the question "Do all the things that I have done has any impact in the hereafter?" Beyond motive (a life after death) always become the parameter of each Moslem individual. On the other hand, philosophic message of Sunan Drajat as a predecessor who has taught Islam in Lamongan and around it has become parameter to every activity in pursuing ideals: 
Findings analysis that has been explained before produced proposition:

"Entrepreneurial characters in Kyai Abdul Ghofur such as optimistic, flexible, perseverance and tough, hard-worker and outcome oriented, opportunities seeker, visionary, motivator, risk-taker, creative, wise and patient, fair and discipline, are the result of his life background. Those characters have become the base to encourage the pursuit of predecessor's ideals as individual and institutional struggle. Those characters have role and contribution to the development and propagation of entrepreneurial spirit in the pesantren and community around pesantren"

\subsection{Strategy Applied by Kyai Abdul Ghofur}

Eentrepreneurial spirit who propagated in PSD besides giving motivation through recitation. Kyai Abdul Ghofur also gives real example through business activities in and around pesantren. As entrepreneur kyai was shown by the ability in dividing time and hard work and also outstanding spirit. As it is said by HPO-18, the department store manager, "Mr. Kyai often says that if you want to be someone, then look at me."

Business units that built are example that Kyai Abdul Ghofur really understands how to introduce entrepreneurial spirit since beginning in PSD environment. As it is quoted in the interview with one of the santri in Sunan Ampel boarding house (HMN-55):

"Mr. Kyai has orientation, I prefer selling my own soto (java soup), selling meatball than working for Chinese", all I know about his spirit in supporting santri to have their own business (thumb up), we are living in this world only once, so don't become a slave. We should be success, don't be slave that means we live just once don't be labor constantly... it is better selling our own soto.... We can eat it if it is not sold out, than being a labor. Support to be autonomous is always..."

ZUQ-28 as Syafi'i boarding house leader

"Kyai often said that santri alumni in this pesantren don't beg for government help, don't beg to become civilian worker, when you are hoping to become civilian worker, automatically you will depend on others...better to sell meatball or anything as long as it is our own work... We are autonomous... I often heard Kyai said that. It gives us motivation so that we are working harder to become someone who is not relying on others... We can be rich by doing many businesses so we can give, we can give whether it is knowledge to others, or it is finance or anything to others."

BET-31 his daughter:

"If we were not rich, how could we give to others? Therefore we have to be rich however the way we get rich by doing businesses... a lot of businesses...therefore we can give either giving knowledge to others or finance to others or anything." 
MMD-6 Muallimin leader, "Don't be afraid with your own shadow."

The santri are so obedient to the Kyai that can be advantageous culture in propagating entrepreneurial spirit. What Kyai said will be obeyed by all his santri. Besides that, the santri will be doing what Kyai said with pleasure. Like one alumni said 'SYD-42', as an advisor in one of the party in Tuban, that Kyai Ghofur as murabbirukhi (life guard) "that my life and my death as in Kyai hand". That kind of obedience has positive impact in entrepreneurship development in PSD. Kyai can manage the direction of his business unit through his instructions. Kyai, through his administrator can ask his santri to help running his business unit that has and will run. The positive side of these processes is that the santri is doing conditionally internship, obtaining experiences, and learning through that process. The negative is that sami'na wa atho'na (listening and obedient) culture can prevent santri in developing their creativity. Santri will become depending and having no initiative and creativity if they were not forced or motivated regularly.

The result of observation shows that pesantren is not only giving examples through the real activity such as business activity but also through other activity such as seminar and training which are held by STAIRA campus. It shows that the propagating of entrepreneurial spirit has become the real agenda which is run in PSD community.

The role of Kyai as a speaker has been used by Kyai Abdul Ghofur as the way to propagate and develop Entrepreneurial spirit in community around PSD. Radio and television media has become the tools to encourage the propagating of entrepreneurial spirit. Although it does not always talk about the importance of entrepreneurial spirit /autonomous spirit, but at some point the speech implied the message of the importance entrepreneurship/autonomous spirit, it gives positive impact to the listener and audience, which are not only from Paciran Lamongan, but it can also from Gresik, Bojonegoro, Tuban, and Jombang. Through his speech, kyai gives his santri warning, advice, motivation, and other real activity that can arouse the spirit of his santri, teacher, and moreover his patient that coming for consultation.

Advices about importance of autonomy are not only given to his santri, but also the teachers who are teaching in pesantren, become the target of Kyai Abdul Ghofur. It showed that Kyai Abdul Ghofur sees a lot of opportunities in this pesantren and also gives the opportunities to the teachers who are involved in the learning process by giving motivation to take the advantage of those opportunities by using it for trading or any entrepreneurial activity. Teacher who has got Kyai Abdul Ghofur 'virus' and has developed his own business is SBK-22, Vocational School of Sunan Drajat teacher. Teacher SBK-22 has developed his own furniture business and felt getting a lot of advantages in doing his business.

The other strategy in developing entrepreneurial spirit has done through the alumni network by being a distributor of one of the product that has been produced in pesantren, for example Aidrat drinking water. It has positive impacts to the development of pesantren business besides giving opportunities to the santri in order to learn business (start up). This strategy is a part of PSD strategy in developing marketing distribution of pesantren products through alumni network spread in Lamongan, Gresik, Tuban, and Bojonegoro. According to IWZ-13 in distributing Aidrat, the alumni network plays key role. The other marketing strategy 
through the night recitation, it is said by Kyai Abdul Ghofur that the inviters are indirectly consuming Aidrat for recitation audiences.

The virus of Entrepreneurial spirit has propagated by Kyai Abdul Ghofur influences all communities through the pesantren speech media. Unfortunately, In PSD community, the curriculum (formal) of entrepreneurship is limitedly given only in SMK and higher education of STAIRA (department of sharia economy). This can be noted that for the propagation enhancement through formal education at school and other education units in around PSD need to be done massively. It needs to be done with the encouragement of the regulation of Minister of Religion Number 17 year 2013 (July) about the implementation of art and entrepreneurship subjects in the level of elementary school (MI), junior high school (MTS) and senior high school (MA).

Kyai Abdul Ghofur is a smart kyai because he has took the advantages of Kyai charisma in pursuing noble goals as his main vision. The visions that come from Sunan Drajat combined with the condition of communities around PSD and social economic development nowadays. Kyai Abdul Ghofur with his charisma has developed the business unit in PSD as part of strategies in propagating and developing entrepreneurial spirit. The developed business units are examples from the guardian for santri and communities around besides as money machine to develop the pesantren autonomously.

Strategy which is developed by Kyai Abdul Ghofur in propagating and developing entrepreneurial spirit in PSD and community around PSD can be seen from the Table 1. The strategic pattern of entrepreneurial spirit propagation done by Kyai Abdul Ghofur can be divided into two patterns, internal and external. Internally, the propagation pattern is involving santri and administrator by doing entrepreneurship training activity, internship for santri in the business unit in pesantren, giving speech to motivate santri, giving examples of the existence of business unit in pesantren, entrepreneurial curriculum especially in SMK Sunan Drajat and STAIRA, and also giving example through his self. Externally, strategy done by Kyai Abdul Ghofur in propagating entrepreneurship virus has done by building networking, cooperation in distributing pesantren products, and also building militancy together with pesantren alumni. Therefore the development and propagation patterns of entrepreneurial spirit that done by Kyai Abdul Ghofur can be visualized as follow Figure 3.

If refer to Peng (2009) about strategy, there was finding that Kyai Abdul Ghofur is visionary without written strategy. All of his strategies are in his mind. Strategy as plan, strategy as action, and strategy as integration as it was said by Peng (2009) are still in the form of action. This is can be understood by Kyai Abdul Ghofur because he knows exactly the condition of the human resources (follower) that exist nowadays.

The above findings analysis has produced proposition:

"Advices, examples and behaviors are the best way in propagating beliefs about the importance of autonomy for individual, institution, community, moreover national autonomy." 


\section{Macrothink}

International Journal of Social Science Research

ISSN 2327-5510

2016, Vol. 4, No. 2

Table 1. Strategy of entrepreneurship development and propagation

\begin{tabular}{|c|c|c|c|}
\hline \multicolumn{4}{|c|}{ Strategy of Entrepreneurship Development and Propagation } \\
\hline Pesantren/santri & Administrators & Alumni & Communities \\
\hline Entrepreneurship training & $\begin{array}{l}\text { Giving motivation to do } \\
\text { business }\end{array}$ & $\begin{array}{l}\text { Business network } \\
\text { (product distribution) }\end{array}$ & Persada Radio and TV \\
\hline $\begin{array}{c}\text { Internship: } \\
\text { Department store staff }\end{array}$ & & Supplier network & \\
\hline $\begin{array}{l}\text { Other business units such as } \\
\text { salt business, mining, } \\
\text { laundry, photocopy and } \\
\text { books, and so on }\end{array}$ & & $\begin{array}{l}\text { Keep the alumni } \\
\text { network stay solid }\end{array}$ & \\
\hline $\begin{array}{l}\text { Propagating entrepreneurial } \\
\text { spirit (speech) }\end{array}$ & & Building militancy & \\
\hline $\begin{array}{l}\text { Giving example with } \\
\text { several business units }\end{array}$ & & & \\
\hline Motivating & & & \\
\hline $\begin{array}{l}\text { SMK of entrepreneurship } \\
\text { department, STAIRA of } \\
\text { sharia economy department }\end{array}$ & & & \\
\hline Example of oneself & & & \\
\hline
\end{tabular}

Source: Processed by the researcher (2014)

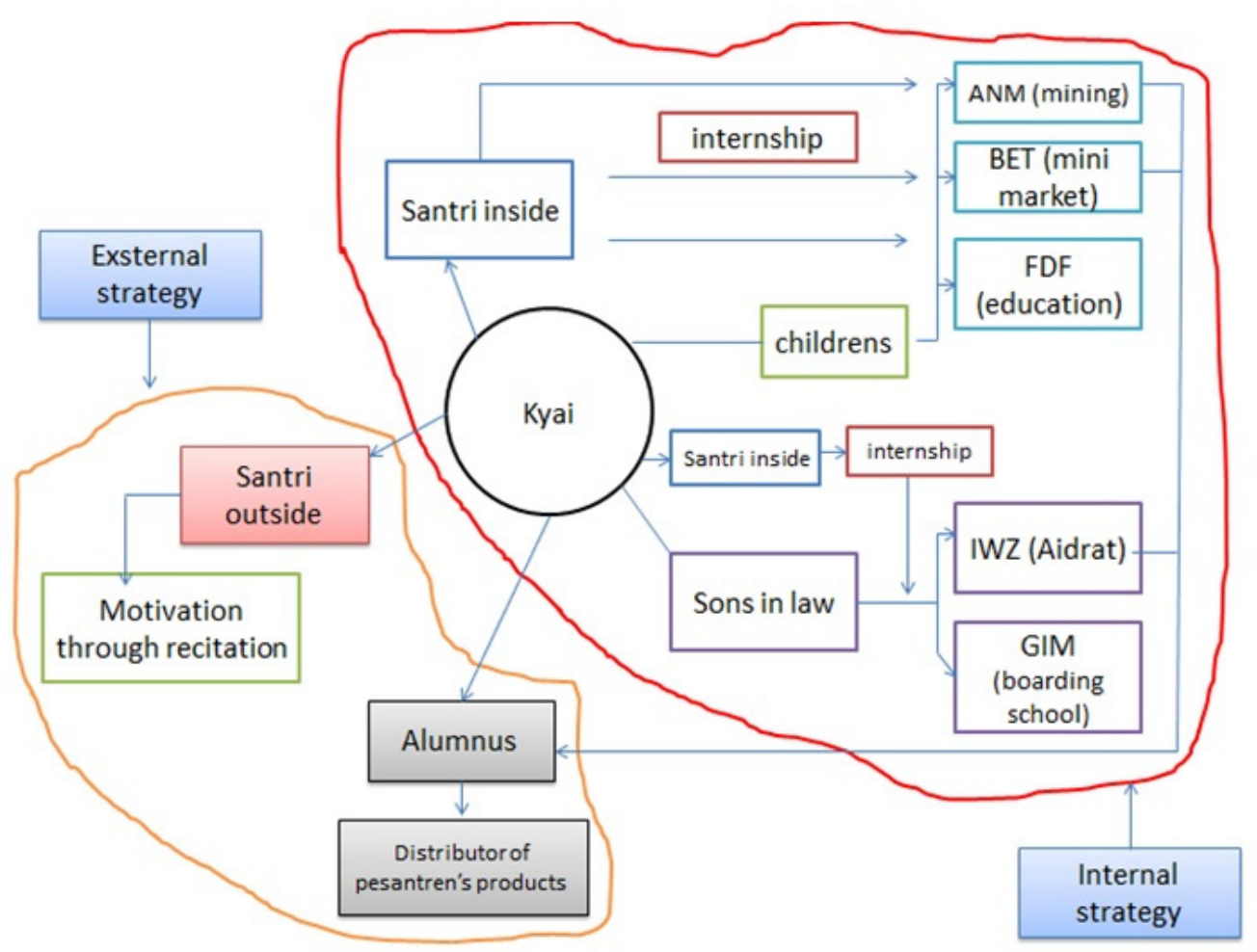

Figure 3. Socio ethnography model of entrepreneurship strategy

Source: Data processed by the researcher (2014) 


\section{Conclusion}

Contributions of the entrepreneurial leadership role of Kyai Abdul Ghofur in the process of developing and propagating the entrepreneurial spirit in Pesantren Sunan Drajat supported by the surrounding culture, or pesantren's culture of sami'na wa ato'na, students who obediently to kyai. The entrepreneurial spirit developed and propagated by Kyai Abdul Ghofur guided by philosophy of 'catur piwulang' from Sunan Drajat. Modern approach and combination of Sunan Drajat philosophy interpretation and supported by a strong leadership style of guided democracy from Kyai Abdul Ghofur and combined with the Sunan Kalijogo philosophy has become an integral part in contributing to the development and propagation of the entrepreneurial spirit in the social environment.

The active role of Kyai Abdul Ghofur in the development and propagation of the entrepreneurial spirit is economic role of the agent in the process of social construction at the pesantren and surrounding communities. Active role motive of Kyai Abdul Ghofur as economic agent is not only driven by the desire for profit alone but also guided by the desire to provide great benefits to the people (prophet motive) through education while maintaining harmonious social relations as recommended of the religion.

\section{Research Limitation and Future Research}

Participative observation needs to be improved by the researcher because only 3-4 days in a week in location to observe. In the future, this research can be developed with leadership theme like spirituality leadership. The other topics can be developed besides the previous topic is spirituality entrepreneurship, family business, Kyai politics or anthropological studies in order to straighten the history of Sunan Drajat, because in the field there are two different versions of story that affirmed the writing of Sjamsudduha $(1998,80-83)$ in his book 'The History of Sunan Drajat in The Entrance of Islam in Archipelago'.

\section{Acknowledgement}

The research is financed by Ministry of Religious Affair of Republic Indonesia 2015.

\section{References}

Abell, D. F. (2006). The Future of Strategy is Leadership. Journal of Business Research, 59, 310-314. http://dx.doi.org/10.1016/j.jbusres.2005.09.003

Akola, E., \& Heinonen, J. (2006). How to Support Learning of Entrepreneurs? A Study of Training Programmes for Entrepreneurs in Five European Countries, Turku School of Economics, Finland. Retrieved May, 2 2013, from http://www.entredu.com/tiedostot/RENTXX_Akola\%20Heinonen.pdf

Al-Quran and Tranlation. (1992). Religion Department of Republic Indonesia. Tunas Inti Semarang Publisher, Semarang.

Antonio, M. S. (2011). Business and Entrepreneurship. Ensiklopedya Leadership and Management of Muhammad SAW. "The Super Leader Super Manager", Tazkia Publishing, Jakarta Selatan. 
Barker, C., \& Coy, R. (2004). The Power of Culture: Driving Today's Organisation. The Australian Institute of Management, McGraw-Hill. Australia Pty Ltd.

Beekun, R. I., \& Badawi, J. A. (1999). The Leadership Process in Islam. A Journal of Ideas, Leaders and Leadership, 16(2), 33-38.

Bogan, V., \& Darity, Jr. W. (2008). Culture and entrepreneurship? African American and immigrant self employment in the United States. The Journal of Socio-Economics, 37, 1999-2019. http://dx.doi.org/10.1016/j.socec.2007.10.010

Bygrave, W., \& Zacharakis, A. (2011). Entrepreneurship (2nd Ed.). John Wiley \& Sons Inc. USA.

Bygrave, W. D. (1994). The Portable MBA in Entrepreneurship. John Wiley, New York.

Carsrud, A. L., \& Brannback, M. E. (2007). Entrepreneurship. Grenwood Press, London.

Casson, M., \& Wadeson, N. (2007). Entrepreneurship and Macroeconomic Performance. Strategic Entrepreneurship Journal, (1), 239-262. http://dx.doi.org/10.1002/sej.35

Central Bureau of Statistics. (2011). Indonesian Population by Province 1971, 1980, 1990, 1995, 2000 and 2010, Retrieved March 22, 2011 from http://www.bps.go.id/tab_sub/view.php?tabel=1\&daftar=1\&id_subyek=12\&notab=1

Central Bureau of Statistics. (2012). Central Bureau of Statistics, East Java Province. Retrieved November 19, 2012, from http://sp2010.bps.go.id/index.php/site?id=35\&wilayah=Jawa-Timur

Creswell, J. W. (2007). Qualitative Inquiry \& Research Design: Choosing among Five Approaches (2nd ed.). Thousand Oaks, CA: Sage

Dhofier, Z. (1982). Pesantren Tradition: Study about Views of Life of Kyai, LP3ES, Jakarta.

Faruqi, I. R.,. \& Faruqi, L. L. (1986). The Cultural Atlas of Islam. Hasan, I. (interpreter), Atlas Budaya Islam, Penerbit Mizan, Jakarta.

Fayolle, A. (2007). Entrepreneurship and New Value Creation; the Dynamic of the Entrepreneurial Process, Cambridge University Press.

Feb. (2012). Unemployment in Indonesai Reach to 7,6 Million,

Fernald, L. W., Jr., Solomon, G. T., \& Tarabishy, A. (2005). A New Paradigm: Entrepreneurial Leadership. Southern Business Review, 30(2), 1-10.

Fetterman, D. M. (2010). Ethnography, Step by Step (3rd Ed.). Sage Publications, Inc., California.

Haedari, A. (2012). The Original Character of Pesantren is Independently. Retrieved April 22, 2013 from http://www.nu.or.id/a,public-m,dinamic-s,detail-ids,5-id,39535-lang,id-c, halaqoh-t,Watak+Asli+Pesantren+itu+Mandiri-.phpx

Hasan. M. (2012). Interview with the Chairman of the Board of Pesantren Sunan Drajat 
Lamongan, November 12, 2012.

Henry, C., Hill, F., \& Leitch, C. (2005). Entrepreneurship Education and Training: Can Entrepreneurship Be Taught? Part II. Education + Training, 47(3), 158-169. http://dx.doi.org/10.1108/00400910510592211

Hodgetts, R., \& Kuratko, D. F. (1995). Effective Small Business Management (5th ed.). Dryden, Fort Worth, Texas. http://dx.doi.org/10.1108/17506200810913944

Kuratko, D. F. (2007). Entrepreneurial Leadership in the $21^{\text {st }}$ Century. Journal of Leadership and Organizational Studies, 13(4), 1-11. http://dx.doi.org/10.1177/10717919070130040201

Landstorm, H. (2005). Pioneers in Entrepreneurship and Small Business Research, Springer Science-Business Media, Inc. Boston. http://dx.doi.org/10.1007/b102095

Li, H. B., Zhe, Y. Y., Xian, G. Y., Haifeng, Z., \& Junsen, Z. (2012). Entrepreneurship, Private Economy and Growth: Evidence From China. China Economic Review, 23, 948-961. http://dx.doi.org/10.1016/j.chieco.2012.04.015

Lincoln, Y. S., \& Guba, E. G. (1985). Naturalistic Inquiry. Newbury Park, CA: Sage Publications. http://dx.doi.org/10.1177/144078338702300329

Lingelbach, D., De La Vina, L., \& Asel, P. (2005). What's distinctive About Growth Oriented Entrepreneurship in Developing Countries? University of Texas at San Antonio-College of Business Center for Global Entrepreneurship, Working Paper. http://dx.doi.org/10.2139/ssrn.742605

Madjid, N. (2012). The Cubicles of Pesantren, Dian Rakyat, Jakarta.

Morden, T. (2007). Principles of Strategic Management (3rd Ed.). Ashgate Publishing Limited, England. http://dx.doi.org/10.4324/9781315602172

Murchison, J. M. (2010). Ethnography Essentials : Designing, Conducting, And Presenting Your Research. Jossey-Bass, San Francisco.

Nadiri, M. I. (2009). Early Muslim Science and Entrepreneurship in Islam. Paper presented at the American Economic Association Meetings.

Nandram, S., \& Samson, K. (2006). The Spirit of Entrepreneurship: Exploring The Essence of Entrepreneurship Through Personal Stories. Springer, Germany. http://dx.doi.org/10.1007/978-3-540-34761-3

Oosterbeek, H., van Praag, M., \& AukeIjsselstein. (2010). The Impact of Entrepreneurship Education on Entrepreneurship Skills and Motivation. European Economic Review, 54, 442-454. http://dx.doi.org/10.1016/j.euroecorev.2009.08.002

Patton, M. Q. (2002). Qualitative Research and Evaluation Methods (3rd Ed.). Sage Publication, California.

Peng, M. W. (2009). Global Strategic Management (2nd Ed.). South-Western Cengage Learning, Canada. 
Pitts, G. (2008). Life as an Entrepreneur: Leadership and Learning. Journal Development and Learning in Organization, 22(3), 16-17. http://dx.doi.org/10.1108/14777280810861776

Putra, Y. M. P. (2012). Pengangguran Indonesia Bertambah 1,3 Juta Orang per Tahun [increased unemployment in Indonesia 1.3 million per year. Retrieved June 20, 2012 from http://www.republika.co.id/berita/nasional/umum/12/05/01/m3crmx-pengangguran-indonesia -bertambah-13-juta-orang-per-tahun

Roesminingsih. (2012). The History of Sunan Drajat in Gold Book of Walisongo, Draft Published (Taken from Prof. Dr. A. Fatchan, MP at Sidomulyo Gg. II Belimbing Malang)

Rofiq, M. (2011). Social Construction of Multidimensional Da'wah of Kyai Abdul Ghofur Paciran Lamongan-East Java, Disertation of Postgraduate Program IAIN Sunan Ampel Surabaya.

Salim, U. (2007). Open Discussion. Magister Management Program Airlangga University Surabaya

Schaper, M., \& Volery, T. (2004). Entrepreneurship and Small Business, A Pacipic Rim Perspective. John Wiley and Son Australia, Sydney and Melbourne.

Sidani, Y. M. (2008). Ibn Khaldun of North Africa: an AD 1377 Theory of Leadership. Journal of Management History, 14(1), 3-86. http://dx.doi.org/10.1108/17511340810845499

Sjamsudduha. (1998). History of Sunan Drajat in Networking Entry of Islam in the Archipelago. Researcher Team of Sunan Drajat History.

Spradley, J. P. (1980). Participant Observation, Library of Congres Cataloging in Publication Data, Copy Right by Holt, Rinehart and Winston, USA.

Spradley, J. P. (1979). The Ethnography Interview. Elizabeth, M. Z. (interpreter), 2007. Metode Etnografi, Edisi kedua, Tiara Wacana, Yogyakarta.

Steiss, A. W. (2003). Strategic Management for Public and Non Profit Organizations, Marcel Dekker Inc., USA.

Strong, M. (2009). Be the Solution: How Entrepreneurs and Conscious Capitalists Can Solve All the World's Problems. John Wiley \& Sons Inc., Hoboken New Jersey.

Sukamto. (1999). Leadership of Kyai in Pesantren, LP3ES, Jakarta.

Sunyoto, A. (2012). Atlas of Wali Songo, The First Book that Reveals Wali Songo For Historical Facts, Pustaka IIMAN, Depok-Jakarta.

Thurik, R., \& Wennekers, S. (2004). Entrepreneurship, Small Business and Economic Growth, Journal of Small Business and Enterprise Development, 11(1), 140-149. http://dx.doi.org/10.1108/14626000410519173

Timmons, J. (1994). New Venture Creation (4th ed.). Irwin, New York.

Van Praag, M. C., \& Versloot, P. H. (2007). What Is The Value Of Entrepreneurship? A 


\section{Macrothink}

International Journal of Social Science Research

ISSN $2327-5510$ 2016, Vol. 4, No. 2

Review of Recent Research. Small Business Economics, 29(4), 351-382. http://dx.doi.org/10.1007/s11187-007-9074-x

Vanderstoep, S. W., \& Johnston, D. D. (2009). Research Methods for Every Day Life, Blending Qualitative and Quantitative Approaches. Jossey-Bass, San Francisco.

Volkmann, C., Wilson, K. E., Mariotti, S., Rabuzzi, D., Vyakarnam, S., \& Sepulveda, A. (2009). World Economic Forum, Educating the Next Wave of Entrepreneurs Unlocking Entrepreneurial Capabilities to Meet the Global Chalenges of the 21th Century. Switzerland. http://dx.doi.org/10.2139/ssrn.1396704

Wolcott, H. F. (1999). Ethnography: A Way of Seeing. Walnut Creek, California.

Zabidi, I. (2002). Mukhtshar Shahih Al-Bukhari, Al-Musamma, At-Tajriid Ash-Shariih li Ahadits Al-Jaami' Ash-Shaih. Zaidun, A. (penerjemah) Ringkasan Hadis Shahih Al-Bukhari, Pustaka Amani, Jakarta.

\section{Copyright Disclaimer}

Copyright for this article is retained by the author(s), with first publication rights granted to the journal.

This is an open-access article distributed under the terms and conditions of the Creative Commons Attribution license (http://creativecommons.org/licenses/by/3.0/). 